\title{
THE FUTURE CONTEXT OF WORK IN THE BUSINESS ENVIRONMENT IN SOUTH AFriCa: SOME EMPIRICAL EVIDENCE
}

\author{
P S Nel and A J du Plessis \\ School of Management and Entrepreneurship, UNITEC, New Zealand \\ A E Marx \\ Department of Business Management, University of Pretoria
}

\begin{abstract}
The future is uncertain, but management needs to determine and also be informed about possible change trends. This research, however, reports on empirical results of the views of South African HRM practitioners to identify and prioritise business change trends for 2002 and 2010 in terms of the "hard" or "soft" HRM debate in the literature. All organisations employing HRM practitioners were included and a total of 1640 questionnaires were distributed resulting in 207 useable responses. The results highlight trends such as increased international competition, globalisation and inadequate skills in different rankings for 2002 and 2010. It is concluded that HRM practitioners, are influenced by the "hard" or "soft" approach when they participate in a strategic management context in organisations.
\end{abstract}

JEL M12, M20(HR)

1

\section{Introduction}

Business executives across the globe know that the rate of change and the accompanying necessity to be abreast of changing business conditions is critical for organisations to compete and prosper. Top executives who are in core management roles should therefore continually adapt their organisations to the changing composition of the competitive business environment in the world of work. The successful management of organisations in a global economy must, however, also endeavour to strike a balance between local conditions and how globalisation impacts on businesses as an absolute given. The identification of change trends is consequently important and the process and involvement of various role players would significantly impact on attempts to identify such trends.

Dawson (2003: 15) outlined a range of "triggers" to organisational change, which organisations must respond to in order to survive. Examples of such factors are: laws and regulations (for example, legislation on age discrimination), globalisation of markets and the internationalisation of business, major political and social events such as advances in technology (computerisation), and organisational growth and expansion. Other factors are the increased movement across borders of people, availability of skills, products, services and availability of capital which of necessity spur renewal in management and organisation practises. The aforementioned are, however, factors which operate on different continuums in organisations, but are not mutually exclusive should the role of human resources management (HRM) practitioners/ managers be factored into the equation to identify future trends.

The general role of HR managers and functional line managers in the world of work are not dissimilar even in slightly different ideological and cultural environments around the world. The role of HR managers within a business is, however, interdependent with that 
of management, because attempts to be mutually exclusive would lead to organisations being in danger of becoming dysfunctional or even perish. HRM and management should therefore cooperate closely to utilise their expertise through mutual support to remain highly competitive in the business world of today and tomorrow to avoid the risk of failure. These particular functions can therefore not be viewed or managed in a silo context without possible serious negative consequences for an organisation either.

Attempts to marginalise the role of HRM in organisations are not uncommon particularly when a narrow so-called "hard" approach to HRM is followed to make it one of the responsibilities of line managers. The interdependency of HR managers and management is thus not as common as might be generally thought, but is often fraught with conflict. It is in fact the focus of a continuous debate, which revolves around the strategic business direction of an organisation regarding the "hard" vs. "soft" approach to human resources management in terms of its management philosophy. The overlap of HRM into line and the reverse has consequently been the subject of debate for years, which has been well researched and published (Ulrich, 1998; Kane, 2001; Storey, 1995; Legge, 1995; Swanepoel et al., 2003; Nel et al., 2004). Various issues have also been identified through the research of Browning and Edgar (2004), based on South African and New Zealand data in particular.

The identification of whether a particular HRM leaning is either towards the "hard" or "soft" approach constitutes the focus of this article in terms of empirical research, executed in South Africa. By only utilising HRM practitioners as participants to identify future change trends, provides a different reality perception of management's traditional strategic environmental scanning role, which is then discussed in this particular research being reported on. The research results identified significant changes in the world of work as well as approaches that affected the management of businesses in South Africa in 2002 but which may be different when identifying possible change trends for 2010.

In the following sections the role of management and the activities of human resources practitioners in terms of the "hard" and "soft" model approach are discussed first. Thereafter, the empirical investigation process is outlined followed by an analysis and comparison of the results. The article is concluded with some observations and conclusions as to the role of HRM practitioners in change trend identification and the leaning or lack thereof to a particular model in a strategic management context.

\section{2}

\section{Trend identification in the business environment}

Over the decades managers have been beset with a variety of trends, including total quality management (TQM), business process reengineering, downsizing, benchmarking, best practice, diversity management, family friendly organisations, outsourcing, environmental sustainability, strategic alliances, learning organisations, knowledge management, ebusiness and the virtual organisation according to Kane (2001). The range of trends or innovations has influenced the theory and practice of management and businesses significantly. Furthermore, factors such as the expansion of global trade and competition and changing customer demands, also suggests that embracing a trend somehow will make organisations better able to adapt to and perhaps even benefit from these changes to compete globally. Various recognised futurist experts worldwide and locally in countries significantly influence businesses acceptance, discounting or application of trends (Ulrich, 1998a; Senge, 1990; Dawson, 2003; Casio, 2000; Sunter, 1999; Nel et al., 2004) to name but a few regarding the business environment.

There is no guarantee that trend predictions by futurists will come to fruition given the complexity and interconnected nature of world events. However, such predictions can eventuate, and global trends posited by Naisbitt 
and Aburdene (1990: 3) for the year 2000 have largely transpired including the rise of the pacific rim, the global economy, cultural nationalism, recognition of the individual and religious revivals, in particular the growth of Islam and fundamentalism.

Examples of trends according to leading futurists are Senge (1990) for organisational learning and Cascio (2000) for virtual organisations. Management trends are a response to a broader societal moral trend, sometimes backed up by business-related legislation. Examples here include diversity management (Bertone \& Esposto, 2000) and environmental sustainability. Nel et al. (2004) reveals that current management trends are to some extent underpinned by the learning organisation focus. These trends include: work process re-engineering, knowledge management, management of intellectual capital, management of the strategic competences of human assets, and the boundary less organisation.

The proponents of trends tend to mount rational reasons as to why an organisation will benefit by the adoption of a trend. Changes in the business environment, such as increased competition are often noted. Cascio (2000: 8182) cites two benefits reported by particular organisations as a result of instituting virtual workplaces: access to global markets without the expense of sending headquarters staff overseas, and environmental benefits through reduced commuting mileage by employees.

Adler (2003) furthermore states that changes in the broader business environment are affecting nearly every aspect of how businesses manage themselves and must take cognisance of the world of diversity in which they operate including outsourcing of the HR function. Conflicting pressures in the labour market have also brought the role of HR to the fore. On the one hand current worldwide need for skills have started the so-called war for talent. Looking forward, demographers predict a long-term tightening of labour skills for the advanced economies of the world but the reverse seem to remain the case for third world countries. Mergers and acquisitions are increasingly frequent, creating huge HR and management challenges as well.

Various forces also affect HR, like the development of technology, which is perhaps the most significant in terms of its impact on managing organisations. From the literature it also appears that the integration between HR and line management should be revisited and the one should not usurp or replace the role of the other, but rather be knowledgeable and supportive of their respective roles. In particular, various ways have been identified in which line management can assist HR professionals to focus on the outcomes in the organisation instead of activities. Furthermore, change management, electronic HR and customised learning for individual performance of organisations' employees is becoming critical, including awareness of due diligence and the influence of government on the South African business environment (Swanepoel et al., 2003; Nel et al., 2004).

In the South African context a particular future concern in terms of trend identification is the impact of AIDS (McDonald, 2005). Some years ago, Vinassa (2002: 4) emphasised the necessity that organisations must deal with AIDS as a serious force shaping the future, since it is now not only a human resources-driven issue in organisations like the mining industry, but should be central to national strategy as well. It is now acknowledged as one of the most important strategic issues facing South African business. The current situation highlighted by the President of Medical Research Council, Prof. Tony Mbewu (2005), is incorrect. This statement concludes that only 2.8 per cent of the natural causes of death could be related to AIDS. This figure should rather be closer to 29.8 per cent of all the natural deaths in the country. AIDS deaths could cause a reduction in GDP of between 0.3 per cent and 0.6 per cent including a decline of 1.3 per cent in population growth. Other estimates by Mbewu are that the national HIV prevalence rate is approximately 25 per cent.

Nel et al. (2004: 584) furthermore indicates that by 2010 the GDP may have decreased by 17 per cent and that 8 million people would be 
affected resulting in a loss of approximately 10 per cent of the then workforce. Furthermore, indirect costs to organisations' employee remuneration could increase by approximately 15 per cent from 2005 to 2010. These sentiments were also echoed by other researchers such as Whiteside and Sunter (2000) who were of the first proponents claiming that adapting a national strategy as a future trend since this is a national pandemic, should at least feature in management's strategic environmental scanning exercises.

A further identification of a South Africanrelated trend highlighted in March 2005 by Minister Trevor Manual when he indicated that the impact of social grants has risen to the point where 10.1 million South Africans are currently benefiting from it. Social grants cost the National Goverment R72.7 billion of the budget and would impact negatively on the economy should it be increased. The social fabric context of future scenarios should therefore also accommodate the impact of the environment within which an organisation operates. In a case like South Africa it would feature as a highlevel change trend concerning the labour market and availability of labour for employment in future.

It is clear that various impacts ranging from highly technical to the more specific peoplerelated issues exist. The reason for the choice and identification of these trends are numerous, but is not the focus of this article. In the context of this article, the human resources point of departure is utilised and therefore a discussion of the context within which the human resources management practitioner operates is discussed in the next section.

\section{3}

\section{"Hard" and "soft" approach to the HR profession}

The forces of change at work in organisations significantly influence perspectives as to what the future role of HRM in organisations' management set-up should be. The debate regarding the "soft" model approach is a developmental humanist approach and for the "hard" model approach a situational contingent approach is followed, but it is neither yet resolved (Story, 1992; Legge, 1995; Boxall, 1996; Kane, 1999; Browning \& Edgar, 2004).

The "soft" approach can be summarised as HRM being effective when it involves a focus, which includes employee motivation, commitment and development. It also reflects the role of management to create a work environment which promotes the employee at work level to participate in communication, have effective training and who are valued (Kane, 2001; Boxall, 1996; Guest, 1989).

The "hard" approach is seen as aligned with strategic HRM and HRM effectiveness and appears to be more contingent upon cost minimisation instead of a more significant investment in human resources (Ulrich, 1997; Legge, 1995; Purcell, 1995; Schuler, 1992; Truss et al., 1997; Storey, 1995; Burton, 2003). However, there do not seem to be a clear-cut approach to what the best "fit" ought to be because theory and practice appears to be divergent in that research often does not match up with what happens in practice. It may, amongst others, result in a failure to consider daily practice of HRM from the point of view of employees instead of HRM merely being concerned about employees (Roehling, et al., 2000; Browning \& Edgar, 2004). Furthermore observations by various authors (Sanchez \& Kepir-Sinangil, 2003; Nel, et al., 2004; Kane \& Crawford, 2001) are that many studies tend to focus only on the views of HR staff regarding particular aspects of HRM. Research is also often focused within a single country or industry sector as opposed to multi-country and cross industry analysis.

A more detailed analysis of the two approaches is clearly warranted to contextualise the effect on trend identification by HRM.

\section{4}

\section{Analysis of the "hard" approach to the HR profession}

In terms of the "hard" approach the HR profession approach needs to bring a strategic view to the management function in 
organisations according to the literature and empirical research. The empirical research of Beaver et al. (2003) and Burchell (2002), for example, found that HR managers must endeavour to create and maintain an organisation that should be able to deliver the plan and strategy of the business by ensuring that the HR strategy is continually aligned with the business strategy. Lipiec (2001) and Kane (2001) again believe that HRM managers need to focus more on the strategic management role of HR. Jayne (2002) furthermore suggests that there must be a tight fit between HR and business strategies in order to cope with identified trends, which invariably influence an organisation's mission and strategies.

Further foci on the future of the HRM profession was outlined sometime ago by Ulrich (1998) where he claimed that the contribution of HR professionals to the organisation's objective achievement can be achieved in four ways, namely: firstly, HR should become a partner with senior and line managers in strategy execution, helping to move planning from the conference room to the marketplace. Secondly, it should become an expert in the way work is organised and executed, delivering administrative efficiency to ensure that costs are reduced while quality is maintained. Thirdly, it should become a champion for employees, vigorously representing their concerns to senior management and at the same time working to increase employee contribution, that is, employees' commitment to the organisation and their ability to deliver results. Finally, HR should become an agent of continuous transformation, shaping processes and a culture that together improve an organisation's capacity for change.

There are indications that the "hard" model approach with a narrow focus on linking strategies to HRM and being predominantly performance focused could ultimately produce negative impacts on employees, which in turn may lead to decreased levels of organisational commitment and employee performance resulting in the easier "walking out the door" of an organisation's strategic assets. This particularly applies to the issues surrounding the debate whether HRM is a line function or not and whether it is "owned" by line and the consequent complications of role strain and role ambiguity which accompanies it. According to Larson and Brewster (2003) the lack of HRM skills of line managers is also becoming part of the debate regarding the future role and functions of the HR profession and which requires further research particularly as far as the debate on the partnership between HR practitioners and line management is concerned. Different views to those proposed by Ulrich (1997) some years ago have recently been reported by researchers (Browning \& Edgar, 2004; Beaver et al., 2003; Burton, 2003, Larsen \& Brewster, 2003) in a regional context, who indicate that HR managers should in fact assume more line role responsibility as part of their training and advancing of the profession than has previously been reported in the literature.

\section{5 \\ Analysis of the "soft" approach to the HR profession}

The "soft" approach has been the focus of analysis and research for a number of years (Beer et al., 1984; Storey, 1992; Legge, 1995a; Roehling et al., 2000; Fitz-enz, 2000; Browning \& Edgar, 2004) to create a work environment which emphasises employee development through training, participation, communication and employees being regarded as valued resources. It is, however, clear that the multiple stakeholder approach to HRM has increased in importance and that the employee viewpoint has gained more prominence recently.

The recent research of Browning and Edgar (2004) in South Africa and New Zealand respectively, have focused on the inputs from the employee point of view and highlights various themes concerning the execution of the HRM practitioner's function in organisations. These are fairness and consistency, communication, training and development, establishing strategy and implementation and responsibilities of the HRM function. The renewed focus on the "soft" model emphasises 
that the profession should pay more attention to the needs in the literature of employees such as flexible working hours, working from home due to the availability of the Internet, training, recognition for high performance, assessments of jobs, and making sure that employees have job satisfaction. HR practitioners should also focus on flexibility, retention, customised rewards raises, bonuses, promotions and open communication channels but also make it easier for employees to progress more quickly from one hierarchical level to the next one.

Furthermore, foci should be developing more flex-time programmes and greater focus on work-life balance including job sharing as a means to better managing an organisation's resources to achieve its goals and to accommodate employee needs more fully (Greef \& Nel, 2003). Clear leadership and accountabilities; a customer focused environment; open communication channels; effective recruitment processes; retention focussed on key skills; effective performance management; competitive guaranteed rewards; flexible packages with an appropriate mix of total rewards; pay linked to business performance and ownership opportunities are also important according to Ison and Barton (2003), Nel et al., (2004) and Hamilton (2003).

The general competencies of HRM are addressed below.

\section{6}

\section{HR profession compentencies for the future}

Various authors have lately noted (Nel et al., 2004; Swanepoel et al., 2003; Hamilton, 2003; Brewster et al., 2000) that a new demands on human resources management is evolving, regardless of the "hard" and "soft" approach model which seems to emphasise the strategic and professional role and functions of human resources managers as a business partner in organisations.

The research of Lipiec (2001) focussed on the future role of human resources management for the next decade (namely 2010+) based on a survey of human resources practitioners. The results revealed that a greater emphasis must be placed on the strategic role of human resources management, teamwork, general management, international and multi-cultural management as well as change management. It is also clear that the profession must play a greater direct role in an organisation's pursuit of its goals and is involved at various levels of management (Birchfield, 2003; Dahmen, 2002; Glade, 2002).

Another identification for the future competency of HRM was identified by Gratton in Burton (2003) who stressed three major challenges facing human resources professionals in organisations namely: first, human resources managers need to become more vocal and influential in the boardroom alongside the financial and marketing directors. Secondly, quantitative skills such as the measurement of human worth and the understanding of organisational structure and dynamics need to be increased for human resources managers to provide effective service in organisations. Thirdly, human resources managers need to develop a new set of skills and competencies around visioning, systems thinking, and organisational development and change management. Human resources managers should therefore execute a visionary and leadership role in the future, which must be strategic in nature.

Specific competencies, however, have also been identified as: foreign language capability; higher level computer literacy; knowledge of intellectual capital resources; experience in key business areas; specialised HR knowledge; line management experience; focus on issues outside of the organisation's social responsibility; enhance teamwork in organisations and to be a major role player in the change management process.

HR practitioners will have to focus on being leaders in the future, yet have to balance the "hard" and "soft" model approach dilemma. 
7

\section{Questionnaire useage and data collection}

In 1994 a comprehensive questionnaire was compiled by the Institutes of Personnel Management of New Zealand and Australia to identify the role and quality of HR in 1994 and estimations for the year 2000 (IPMNZ, 1994). The questionnaire was originally compiled after consultations with industry and an analysis of the literature as well. Burchell (2001) modified the questionnaire slightly in association with The Human Resources Institute of New Zealand (HRINZ) for follow-up research in New Zealand. The changes involved editorial updating and scrapping of a section on Human Resources Information Systems, because the questionnaire was too long which caused reduced survey responses. Trends were also analysed and edited for the survey in New Zealand and also for South Africa.

The same questionnaire was used with permission after minor editorial modifications for an identical survey in South Africa. It was not deemed necessary to update it after the researchers evaluated it. Any significant changes from the original questionnaire would have invalidated any comparisons or reliability with New Zealand, which was one of the overriding objectives of the larger research project. The topics covered in the questionnaire included human resource goals, roles and activities, HR staffing and implications of changes for management in the business environment. The final section of the questionnaire sought to obtain demographic information from respondents. Due to the magnitude of the survey only a small section is analysed and reported upon in this article. The results are contained in Table 3, where the questions and the results are presented in a consolidated format.

Data collection approach. The questionnaire was distributed to 100 per cent of the paid-up members of the Institute of People Management (IPM) in South Africa. It resulted in 1,640 questionnaires being mailed to organisations throughout South Africa employing paid up and thus registered HR practitioners. The response cut-off date was the end of March 2003.

The response rate is statistically significant, since 207 useable responses, that represent a 12.5 per cent response rate could be used for the data analysis. However, as the questionnaire was sent to 100 per cent of the paid-up members of the IPM practitioners, it follows that the results are highly representative of the mentioned professions perception of the future. This is also supported by the similarities of the demographic responses outlined below.

\section{8}

\section{Demographic responses and results}

In terms of reliability the South African results are consistent with the relative position and results of the New Zealand demographic responses for both the profession profile and relative number of employees employed in organisations. The employee average for both below 100 and above 100 from the responding organisation is also compatible with the New Zealand results profile (see Tables 1 and 2).

Table 1

Profile of respondents by profession

\begin{tabular}{|l|c|}
\hline Profession & $\begin{array}{c}\text { South African } \\
\text { profile (\%) }\end{array}$ \\
\hline $\begin{array}{l}\text { Human resources (from officer } \\
\text { to director of HR) }\end{array}$ & 68.0 \\
\hline $\begin{array}{l}\text { Business (line managers to CEO) } \\
\text { who were ex-HR }\end{array}$ & 11.4 \\
\hline HR consultants & 9.2 \\
\hline $\begin{array}{l}\text { HR academic (all tertiary } \\
\text { educational institutions) }\end{array}$ & 7.4 \\
\hline $\begin{array}{l}\text { Other HR not included in above } \\
\text { classification }\end{array}$ & 4.0 \\
\hline TOTAL & $\mathbf{1 0 0}$ \\
\hline
\end{tabular}

The overall profile of the respondents is also highly compatible for the SA business community as shown in Table 1 . The overall profile of the respondents in terms of organisation size is also highly compatible. It 
also lends credence to comparisons of their perceptions in terms of the HR profession's representative organisational profile by size and industry in South Africa as shown in Table 2. Any differences that might exist could safely be attributed to the perception of the respondents regarding the current or future situation with regard to the research result issues.

Table 2

Profile of respondents by organisation size

\begin{tabular}{|l|c|}
\hline $\begin{array}{l}\text { Number of employees in } \\
\text { organisation }\end{array}$ & $\begin{array}{c}\text { South African } \\
\text { profile (\%) }\end{array}$ \\
\hline Fewer than 10 & 2.5 \\
\hline $10-49$ & 6.2 \\
\hline $50-99$ & 8.1 \\
\hline $100-499$ & 15.7 \\
\hline 500 or more & 67.5 \\
\hline TOTAL & $\mathbf{1 0 0}$ \\
\hline
\end{tabular}

For the purpose of this analysis, only the result of one particular section of the overall large survey is discussed as was outlined elsewhere in this article. The respondents had to identify and separately rank the five most significant changes from a provided list of 20 items in the questionnaire, in terms of the current situation and 2010 plus. The 20 questionnaire change trends represented 10 "soft" and 10 "hard " identifiable statements, which were randomly ranked in terms of the discussion context outlined elsewhere in this article.

In terms of ranking, the most important choice made by a respondent for the future was 1 being the highest impact, 2 the next highest and so on. The top six change impacts are listed and reported on in Table 3. The remaining statements not chosen by respondents are listed below and are not discussed further in this article, due to their lower rankings, although recognised as impact trends.

- Growth in non-traditional business structure, e.g. business alliances, joint ventures
- Increased reliance on automation or technology to produce goods and services

- More sophisticated information or communication technology

- Changing attitudes of society towards business

- Heightened concern about pollution and natural resources

- Heightened focus on total quality or customer satisfaction

- Changing employee values, goals and expectations, e.g. less loyalty to employers

- Inadequate skills of entrants into the workforce

- Changing composition of the workforce with respect to gender, age, and/or ethnicity

- Growth of electronic business

- Increased energy costs

- Crossborder application of employee rights

- Greater concerns about the confidentiality of personal information

The percentage figures in each column in Table 3 represent the number of respondents who ranked the items according to their choice. For ease of reference the ranking of items in terms of current impacts (that being 2002) and future (that being 2010) is numbered separately in subscript format next to the percentage response, as different impacts feature in different rankings for the various time periods being compared.

Each completed questionnaire was subjected to verification for completion accuracy before responses were collated and statistical analysis was used to analyse the overall responses in terms of the percentage responses.

Only the top 6 changes as impacts are presented for analysis purposes and are presented in descending order of importance from 1 to 6 in Table 3. In order to include the analysis for both time periods for comparative purposes, the 2002-year is regarded as current for the purpose of the article. 
Table 3

The current and anticipated changes in the business environment as perceived by $\mathrm{HR}$ practitioners

\begin{tabular}{|c|c|l|c|c|}
\hline \multicolumn{2}{|c|}{ 2002 Ranking } & \multirow{2}{*}{ Business Environment areas } & \multicolumn{2}{c|}{$\mathbf{2 0 1 0}+$ Ranking } \\
\cline { 1 - 3 } SA \% & Issue & & SA \% & Issue \\
\hline $66.67_{1}$ & Hard & Increased national/international competition & $69.23_{1}$ & Hard \\
\hline $65.56_{2}$ & Hard & Increased governmental regulation & $45.96_{5}$ & Hard \\
\hline $60.42_{3}$ & Hard & Globalisation of corporate business structure & $59.62_{2}$ & Hard \\
\hline $44.83_{4}$ & Soft & Harnessing knowledge management and intellectual capital & $45_{.14_{6}}$ & Soft \\
\hline $40.96_{5}$ & Soft & Inadequate skills of entrants into the workforce & - & \multirow{2}{*}{-} \\
\hline $40.45_{6}$ & Hard & Globalisation of the economy/break-down of trade barriers & $53.67_{4}$ & Hard \\
\hline- & - & Few entrants into the workforce & $55.33_{3}$ & Soft \\
\hline
\end{tabular}

First change impact for 2002 and 2010: Increased national/international competition. The results indicated that 66.67 per cent of the respondents rated this as the top change impact for the future on business in South Africa. This is in line with the identified priority of Sunter (1999) regarding much needed international competition. It may be ascribed to South Africa's recent re-entry into world markets and that competition will increase in future. South African business managers should therefore prepare for this impact as a definite eventuality.

Respondents in South Africa also selected this as the top impact for 2010 with a response of 69.23 per cent. It therefore appears that the situation is similar for South Africa for 2010 concerning increased national or international competition. From the higher response it may be deduced that they are anticipating improved capability to cope with this situation. It can, however, be concluded that increased national and international competition will remain the greatest impact on business for at least the next decade and more for South Africa, and managers must certainly learn how to deal with the changed environments.

From the overall result it is clear that the choice by HRM practitioners for both time periods is identified as a "hard" issue, which consequently clearly indicates a necessity on their part to think strategically and effect on bottom line for organisations. Thus, regardless of the fact that the respondents are HR practitioners, a typical strategic line management issue was the top priority.

Second change impact for 2002 and 2010: Increased governmental regulation: Respondents rated this impact as second highest with a response of 65.56 per cent in 2002, which clearly indicates that they perceive government regulation presently as high as an impact and change issue. This is noteworthy in terms of governmental involvement in the business environment.

Respondents only rated this impact as the fifth highest for 2010 and beyond with a response of 45.96 per cent.

Governmental regulation appear to be less influential by 2010 in terms of its impact and has less impact on the world of work than is generally thought to be the case. It can also be deduced that the free market spirit is envisaged to gain momentum up to and beyond 2010 with slightly increased government regulation being an outside change option.

Once again a "hard" issue was identified and although a different trend gained second place, it was again considered to be a fully-fledged management category of strategic bottom line influence on an organisation.

Third change impact for 2002 and 2010: Globalisation of corporate business structure: The response rate was 60.42 per cent for South Africa, which is a clear indication that respondents view business expansion as very important and that business structures 
must change to accommodate global business. It could be due to South African businesses only realising now that entering global markets requires a focus on changed business structures as well. This is supported by the first change impact discussed above namely that national and international competition (as the top impact priority) can only be effective if commensurate adjustments in business structures to cope with such competition are put in place. This change trend is also identified by the research of Swanepoel et al. (2003).

Respondents gave a rating at 59.62 per cent for 2010, which is the second highest impact for that period, which confirms a global focus of businesses, but that structural adjustment is still a very high priority. It can be deduced that respondents believe that globalisation of business structures is an important business development and will remain so even past 2010. It can be concluded that organisations not only face more international competition (as highlighted above) but that global business and the accompanying structures will evolve in a truly international business fashion that operates throughout the globe in future. The results support the trend that economic growth in world markets and changed corporate structures are important in future in the management of businesses, which implies that managers can learn from each other in this regard.

Once again a "hard" issue was identified for 2002 and even increased its rating for 2010 signalling a clear preference for "hard" approach issues by HRM practitioners again. However, a different trend regarded as a "soft" issue, namely number of entrants into the workforce, have taken third place in 2010 indicating that the HRM profession concern of a "soft" issue has risen sharply in the priority list for the future. The AIDS pandemic and employee related consequences for South Africa as a whole may have given rise to this choice by HRM practitioners.

Fourth change impact for 2002 and 2010: Harnessing knowledge management and intellectual capital: A total of 44.83 per cent of South African respondents rated this as the fourth most important impact and therefore a possible trend for the future. It is surprising that it is such a low priority, but not surprising because since it is expected to be the case in terms of knowledge management and learning organisations, which have been dominating the business world thinking for more than a decade (Senge, 1990). It is deduced that for South Africa it is critical for the future, which is consistent with world trends in this field as identified by various researchers Buyens et al. (1997), Swanepoel et al. (2003) and Nel, Marx \& Burchell (2004).

The change impact for 2010 had a response of 45.14 per cent for South Africa, which is still slightly higher than 2002, although it was rated as the sixth highest impact for that period and further. The results concur with the research reported by Firer and Saunders (2003: 17) regarding the importance of intellectual capital. Managers must therefore be fully cognisant of this issue in future.

It is only with the fourth highest impact ranking that a "soft" issue has gained a place in the priorities for 2002, whilst a "hard" issue actually gained this ranking in 2010 (namely globalisation of corporate business structure and breaking down of trade barriers). This clearly indicates the difficulty of choice and the dilemma between "hard" and "soft" issues as faced by HR practitioners in terms of the challenges facing business. Circumstances therefore dictate to HRM practitioners how to react in a strategic business context.

Fifth change impact for 2002 and 2010: Inadequate skills of entrants into the workforce: With a response rate of 40.96 per cent it is recognised that businesses are facing a skills deficiency in South Africa, which is obvious for various historical reasons. This will continue to have an immediate impact in the future as was pointed out by the research of Haasbroek (2004: 399) and also by Barker (2002). The workforce is not fully integrated into the economy in South Africa.

Cross border issues did not feature in the South African perception of the future. It is quite surprising if it is borne in mind that South Africa has entered into closer relations with bordering 
nations in the Southern African region. The ongoing political instability in Zimbabwe may also be a strong indication as to why it does not feature as an impact. If South African business managers are to be fully aware of these changed issues, then they should take cognisance of the way in which employee rights evolved.

Regarding 2010 and further it was very surprising that respondents did not perceive this impact as of any importance. It may be that training and development, upskilling and the attraction of workers internationally may solve this problem. A further wildcard may be that the AIDS pandemic as outlined by Whiteside and Sunter (2000) and Nel et al. (2004) will most probably decrease the economically active population and cause serious economic decline by 2010 . Consequently as an outside possibility it may be that there would be sufficient skills available to run a contracted economy without serious skills shortages.

HRM practitioners raised a "soft" issue in this case in that a clear identification of the shortage of skills of the workforce has been highlighted. These sentiments are again confirmation of the trend identification by Vinassa (2002) and Nel et al. (2004) in that it is a national urgency that more "soft" issues need to gain centre stage. In 2010 however, a "hard" issue namely increased governmental regulation once again took this priority, which indicates that changed time frames could change the priority regarding a "soft" or "hard" choice issue.

Sixth change impact for 2002 and 2010: Globalisation of the economy or breakdown of trade barriers. This impact is addressed due to its upgraded position for 2010, which became the fourth most important impact. For 2002, however, it only attracted a response rate of 40.45 per cent.

In analysing the result for 2010 and onwards, it is in fact the fourth highest change impact with a response of 53.67 per cent for South Africa. This impact change issue is in line with the critical role of countries trying to break into international markets and is also supported by the research of Barker (2002). The relative isolation of South Africa in this regard necessitates an approach of this nature to grow the economy. Business managers must therefore be mindful of strategies to enhance globalisation and growth. It can be deduced that the increased response regarding entry into global markets through the repositioning of the economy is critical. This result appears to be in support with Parmenter's (2002: 36) view that it is important in terms of HR's value adding role to enhance globalisation, albeit is a relatively lower priority in terms of the current research results.

Once again, a "hard" issue was chosen as priority for the sixth place. However, it increased to a fourth priority in 2010 indicating a relative value to HR practitioners in the future. A "soft" issue has slipped back to sixth namely harnessing knowledge management and intellectual capital for the future in the 2010 results.

\section{9}

\section{Discussion and conclusions}

From the analysis of the research results it is clear that the choice of impact trends change noticeably from 2002 to 2010 as perceived by human resources managers. It is also clear that HR practitioners could equally well function in a strategic role in organisations. Even more so the traditional roles of line managers could be enlarged to accommodate inputs from HRM practitioners with limited risks. The empirical results largely concur with the literature that the perspective of HR managers may have some value for the management of businesses in identifying trends, since a mix of a "soft" and "hard" issues in organisations are reflected.

The perception of HR managers with regard to the management of organisations in identifying envisaged new trends in the world of work should identify some critical challenges from which managers need to take cognisance and propose remedial action. HRM involvement in line should therefore not be seen as a threat to management's strategic function, but rather complement it. The "hard" approach is more prevalent and supported by the research results. It also reflects HRM perspective of the business landscape in South Africa for 2002 and 2010 onwards. 
The results clearly indicate that South African HR practitioners' involvement in strategic management issues impacting on organisations correspond with empirical studies executed elsewhere in the world such as New Zealand, Australia (Kane, 2001; Edgar \& Browning, 2004; Burchell, 2002).

It appears that in terms of the literature perspective that South African HR practitioners' views of the future are not dissimilar from the global context envisaged for 2002 to 2010 (Ulrich, 1998; Storey, 1995; Du Plessis, 2004). It can be concluded that South Africa's integration into the national and international business fold is palpable, but that some warning signs have, however, been identified for businesses from the HR practitioners' perspective in that particular "soft" model issues were raised.

It can also be concluded that the division between HR management and line management, as far as cooperation and sharing of line HR responsibility is concerned, is narrow in terms of the "hard" approach to HRM when choices are made in a strategic management environment. It is noteworthy to point out that in allocating priorities, HR practitioners' first choose "hard" approach options and then "soft" items from the change trends list in the survey. The conclusion reached in this research is that the "soft" approach concerning identification of change trends, which could be considered to be strategic, are less prominent than the "hard" approach. In fact the "hard" approach and viewing the future from a strategic point of view, appears to once again highlight the dichotomy in the literature regarding the continuing debate to reconcile the "soft" and "hard" approach with regard to HRM functioning in organisations.

Continuing research regarding this debate could identify the way to more cooperation between management and HRM in South Africa to achieve better synchronised policies and strategic direction when dealing with the future. It could also culminate in less friction within organisations in the establishment of vision and dealing with issues relating to resource allocation and/or dealing with future opportunities and threats facing organisations.
South African executives in particular and businesses elsewhere in the world in general, could also benefit greatly from the knowledge unlocked in the research results reported in this article and future areas that were outlined as well.

\section{References}

1 ADLER, P.S. (2003) "Making the HR outsourcing decision," MIT Sloan Management Review, 45(1): 53-61.

2 ALLEN, C. (2003) "Y - You should care", Employment Review, Australia. 1(1): 27-29.

3 BAKER, G. (2003) "Situations vacant", New Zealand Business, 17(1): 37-41.

4 BARKER, F.H. (2002) The South African Labour Market, $4^{\text {th }}$ ed., Van Schaiks: Pretoria.

5 BEAVER, B.; NEL, P.S. \& DU PLESSIS, A.J. (2003) Human resource management goals and roles: A New Zealand and South African comparison for the first decade of the new millennium, Proceedings of the $17^{\text {th }}$ annual conference of the Australian New Zealand Association of Management, Freemantle, 5-7 December.

6 BEER, M.; SPECTOR, B.; LAWRENCE, P.; QUIN MILLS, D. \& WALTON, R. (1984a)

Human resources management: A general manager's perspective, Free Press: Glen Coe, IL.

7 BERTONE, S. \& ESPOSTO, A. (2000) "Turning diversity into dollars: Productive diversity in Australian business and industry", International Employment Relations Review, 6(1): 141-156.

8 BIRCHFIELD, R. (2003) "The future of HR. What are the critical issues", Management, 50(7): 45-48.

9 BOXALL, P. (1996) "The strategic HRM debate and the resource-based view of the firm", Human Resource Management Journal, 6(3): 59-75.

10 BREWSTER, C.; DOWLING, P.; GROBLER, P.; HOLLAND, P. \& WARNICH, S. (2000) Contemporary issues in human resources management. Gaining a competitive advantage, Oxford: Cape Town.

11 BROWNING, V. \& EDGAR, F. (2004) "Reactions to HRM: An employee perspective from South Africa and New Zealand" Journal of the Australian and New Zealand Academy of Management, 10(2): 1-13.

12 BURCHELL, N. (2002) 1994 to 2010: Future directions for HR in New Zealand, Unitec: New 
Zealand, http://www/hrinz.org.nz/info/hot_stuff/ conference/noel_burchell.asp

13 BURCHELL, N. (2001) 2000 to 2010: Future directions for HR in New Zealand, Auckland: New Zealand, Unitec: New Zealand.

14 BURTON, L. (2003) "The Next Big Thing", People Dynamics, 21(2): 22-23.

15 BUYENS, D.; VAN SCHELSTRAETE, S.; DE VOS, A. AND VANDENBOSSCHE, T. (1997) HRM in transitie: Via het 'toegevoegde-waardedenken' naar een Human Investment Strategie, Jan van den Niewenhuizen, Antwerpen, Belgium.

16 CASCIO, W.F. (2000) "Managing a virtual workplace" Academy of Management Executive, 14(3): 81-90.

17 DAHMEN, C. (2002) "The recipe for HR success", Management, 49, 29.

18 DAWSON, P. (2003) Understanding organizational change. The contemporary experience of people at work, Sage Publications, London.

19 DU PLESSIS, A.J. (2004) "Conflict during the changing process: Human resources' role in 2002 and in 2010", IFSAM $7^{\text {th }}$ World Congress, 5-7 July, Goteborg, Sweden.

20 FIRER, S. \& SAUNDERS, S. (2003) "Human Capital Measurement”, People Dynamics, 21(3): 17-19.

21 FITZ-ENZ, J. (2000) The ROI of human capital measuring the economic value of employee performance, Amacom, New York.

22 GLADE, B. (2002) "Emerging trends in HR: A view from a big place" Human Resources, 7(1): 14-15.

23 GREEF, A. \& NEL, P.S. (2003) "Employment transformation enhancement in South Africa: Establishing a job-sharing model to promote employment equity", South African Journal of Labour Relations, Winter, 27(2): 23-62.

24 GUEST, D. (1989) "Personnel and HRM: Can you tell the difference?" Personnel Management, 21(1): 48-51.

25 HAASBROEK, G.D. (2004) "National level skills development issues", In: Nel, P.S.; van Dyk, P.S.; Haasbroek, G.D.; Schultz, H.B.; Sono, T. \& Werner, A., 2004, Human resources management, $6^{\text {th }}$ ed., Oxford University Press: Cape Town: 392-423.

26 HAMILTON, N. (2003) "HR'\$ Currency", Employment Review, (Australia), 1(2): 10-11.

27 INSTITUTE OF PERSONNEL MANAGEMENT NEW ZEALAND. (1994) "Human resources priorities for competitive advantage. 1994-2000”, The IPM survey report,
Auckland: New Zealand: Institute of Personnel Management, New Zealand.

28 ISON, J.P. BARTON. (2003) "Future Fillips", Employment Review, Australia, 1: 34-35.

29 JAYNE, V. (2002) "At the crossroads. Is Human Resource Management on the right track? And where exactly is it headed?", Management, 49: 26, 28, 30.

30 KANE, B. (2001) "HRM and trends in management: Travelling a well-worn path?" Paper presented to $15^{\text {th }}$ Annual ANZAM Conference, 6-8 Dec., Auckland, New Zealand.

31 KANE, B. \& CRAWFORD, J. (1999) "Barriers to effective HRM", International Journal of Manpower, 20(8): 494-512.

32 LARSEN, H.H. \& BREWSTER, C. (2003) "Line management responsibility for HRM. What is happening in Europe?", Employee Relations, 25(3): 228-244.

33 LEGGE, K. (1995) Human resource management: Rhetoric's and Realities, MacMillan: London.

34 LIPIEC. (2001) "Human resource management perspective at the turn of the Century", Public Personnel Management, 30(2): 137-145.

35 McDonald, L. (2005) "HIV/AIDS treatment for employees - where are we?", People Dynamics, 23(4): 24-25.

36 MEDICAL RESEARCH COUNCIL. (2005) "AIDS causes up to $0.6 \%$ drop in SA GDP", Speech by Prof. Tony Mbewu, March, Pretoria, South Africa.

37 NAISBETT, J. \& ABURDENE, P. (1990) Megatrends, 2000, Pan Books: London.

38 NEL, P.S.; MARX, A.E. \& BURCHELL, R.N. (2004) "Management challenges regarding the future of work and change: Human resources managers' perspective for the following decade", IFSAM $7^{\text {th }}$ World Congress, 5-7 July, Goteborg: Sweden.

39 NEL, P.S.; VAN DYK, P.S.; HAASBROEK, G.D.; SCHULTZ, H.B.; SONO, T. \& WERNER, A. (2004) Human resources management, $6^{\text {th }}$ ed., Oxford University Press: Cape Town, South Africa.

40 PARMENTER, D. (2002) "How HR Adds Value", New Zealand Management, 49: 36-37.

41 PURCELL, J. (1995) "Corporate strategy and its link with human resource management strategy in: Storey, J. (ed.)", Human resource management: A critical text, Routledge: London.

42 ROEHLING, M.Z.; CAVANAUGH, M.A.; MOYNIHAN, L.M. \& BOSWELL, W.R. (2000) "The nature of the new employment relationship: 
A content analysis of the practitioner and academic literatures", Human Resource Management, 39(4): 305-320.

43 SANCHEZ, J.I. \& KEPIR-SINANGIL, H. (2003) "Scanning the environment of human resources management in Europe and in the U.S.: So far and yet so close", The International Journal of Organizational Analysis, 11(2): 153-160.

44 SCHULER, R.S. (1992) "Strategic human resource management: Linking the people with the strategic needs of the business", Organizational Dynamics, 21(3): 18-32.

45 SENGE, P.M. (1990) The fifth discipline: The art and practice of the learning organisation, Century Press: London.

46 SOUTH AFRICAN PARLIAMENT. (2005) "SA cannot afford higher social grants", Speech by Trevor Manual, March, South Africa.

47 STOREY, J. (1995) "Human resource management, still marching on or marching out?" In: Storey, J. (ed.), Human resource management: A critical text, Routledge: London.

48 STOREY, J. (1992) Developments in the management of human resources, Basil Blackwell: Oxford.
49 SUNTER, C. (1999) Never mind the millennium. What about the next 24 hours?, Human \& Rousseau: Cape Town.

50 SWANEPOEL, B.J.(ED); ERASMUS, B.J.; VAN WYK, M. \& SCHENK, H. (2003) South African human resources management. Theory and Practice, $3^{\text {rd }}$ ed., Juta: Cape Town, South Africa.

51 TRUSS, C.; GRATTON, L.; HOPE-HAILEY, V.; MCGOVERN, P. \& STILES, P. (1997) "Soft and hard models of human resource management: A reappraisal", Journal of Management Studies, 34(1): 53-73.

52 ULRICH, D. (1998) "A new mandate for human resources", Harvard Business Review, 76(1): 124135.

53 ULRICH, D. (1998a) "The future calls for change", Workforce, 77(1): 87-92.

54 ULRICH, D. (1997) Human resource champions: The next agenda for adding value and deliver results, Harvard Business School Press: Boston.

55 VINASSA, A. (2002) "Measure, monitor and manage", People Dynamics, June/July, 20(5): 4-5.

56 WHITESIDE, A. \& SUNTER, C. (2000) AIDS. The challenge for South Africa, Human \& Rossouw: Cape Town. 